\title{
Autofiction, Post-conflict Narratives, and New Memory Cultures
}

\author{
Hywel Dix
}

It has now been established that a reaction against the idea of the death of the author provided one of the contexts in which autofiction developed in the 1970s. The autofictional rebuttal of the death of the author has been very noticeable among postcolonial writers, who, because their voices and experiences had been historically marginalized until the very recent past, are unlikely to accept the tacit silencing of those same voices that theories of the death of the author might entail. More specifically, two of the elements of autofictional practice that have been of particular interest to postcolonial writers are its capacity to mediate between individual and collective forms of memory, on the one hand, and, at the same time, to radically destabilize notions of absolute truth and authenticity. Drawing on current research into the relationship between writing and forms of public commemoration, this chapter argues that the tools and techniques afforded by autofictional modes of writing have been taken up by postcolonial writers seeking to draw attention to a number of atrocities that took place during or shortly after the colonial period.

H. Dix (四)

Bournemouth University, Poole, UK e-mail: HDix@bournemouth.ac.uk

(C) The Author(s) 2022

A. Effe, H. Lawlor (eds.), The Autofictional, Palgrave Studies in

Life Writing, https://doi.org/10.1007/978-3-030-78440-9_10 
Through a discussion of Chimamanda Ngozi Adichie's depiction of Nigeria's Biafran War of 1967-1970 in Half of a Yellow Sun (2006) and Justin Cartwright's reflection on the massacre of Zulus by Boers in 1838 in Up Against the Night (2015), the chapter will show how these writers contribute to new forms of public memory and hence to post-conflict reconciliation. In doing so, their work can be said to make innovative use of some of the techniques associated with autofiction-not so much because the historical stories they tell are exactly their own, but because these authors feel they have a personal stake in them. That is, Cartwright and Adichie use those techniques to draw attention to the fraught nature of the process of remembering and therefore both contribute to and complicate the process by which we collectively remember traumatic events that have been neglected for decades, if not centuries. At the same time, these authors also enrich our understanding of what we mean by the elusive term "autofiction."

\section{Singular Collective Voices}

Analysis of autofictional texts has so far focused overwhelmingly on prose fiction, with important theoretical studies by Vincent Colonna (2004), Max Saunders (2010), Lut Missinne (2019), and Marjorie Worthington (2018) treating textual exegesis of the printed novel as the primary objective of autofictional inquiry. Yet, as autofiction presumes a close identification between author and protagonist, the only means by which this identification can be apprehended is through recourse to a range of paratextual material - the consideration of which shifts critical attention away from the bounded text. For this reason, Allira Hanczakowski (2020) has recently argued that works of autofiction need to be discussed in the context of their paratexts. Even the briefest consideration of autofictional paratexts points to a dialogic interplay between intra-textual and extratextual dimensions in Serge Doubrovsky's original definition in the blurb for Fils (1977), according to which autofiction is constituted when the protagonist and author share a name and identity in a work which is designated a novel. On the one hand, the concern with the protagonist points inward toward the textual object, in a move orientated toward its interpretation and extrapolation on an aesthetic level. On the other hand, the generic categorization of any given work takes place just outside the limits of the text itself within its epitexts and peritexts, in all those material aspects of the work that are of the text but not in it. 
This move from text to paratext has significant implications for how we think about the position of autofiction vis-à-vis contemporary memory cultures. Within the field of autobiography studies, the diminishment of the idea of a sovereign self was one of the occasions for Doubrovsky's development of the concept of autofiction. In effect, it replaced the idea of the authorial self with a multiplicity of different textual selves. As character is a construct and constructs are historically contingent and variable with circumstance, a single ostensible author could evince as many different selves as there are narrative occasions for their expression. This, of course, is the basis of Camille Laurens's unconventional shift in conjugation of the verb "to be," from "I am" to "I are":

What interests me in particular, undoubtedly because I have seen its effects within myself, is the question of splitting. The ego is not fixed, we do not have a single monolithic identity, we are made up of the tensions between our different personal avatars. 'I are,' we should say. $(2016)^{1}$

Pushing Laurens's idea of the multiplicity of selves a stage further, this chapter proposes that the conjunction of "I" with "we" implicit in the "I are" of autofiction can usefully be articulated in the genesis of new forms of memory culture. This is because, as a mode of writing that involves a dialogic interplay between text and paratext, autofiction has the capacity to recall to public consciousness brutal episodes from the colonial past which have been left to drop out of public memory, giving rise to a collective silence and forgetting which certain authors feel a direct personal responsibility for re-presenting. In the process, they challenge that cultural amnesia at simultaneously an individual and a collective level of discourse, so that autofiction has the capacity to enact an integration of subjective narratives with concerns that are social and historical, or of "I" with "we," and so re-inscribe expressions of collective experience.

In my 2020 paper "Autofiction, Colonial Massacres and the Politics of Memory," I explored how Fred D'Aguiar's Feeding the Ghosts (1997), Jackie Kay's “Lament for the Mendi Men" (2011), and Kamila Shamsie's $A$ God in Every Stone (2014) engaged in a writing practice that attempts this re-inscription of collective experience in bringing to light a number of incidents from the colonial past that have unjustly been allowed to lapse out of public consciousness (Dix, 2020). Strictly speaking, their work is not autofiction in Doubrovsky's sense. Although based on real historical events, the experiences narrated are not the authors' own, so it is 
impossible for the authors to appear as protagonists under their own names. This means that, if autofiction is treated as a genre, these works cannot be assimilated to it. But simply debating whether a given text can be defined as autofiction in a categorical sense is a theoretical cul-de-sac, at best a ludic game and at worst a critical distraction from the more important themes and questions that they raise. A more fruitful way of talking about these texts is in terms of autofictional modes of reading they enable. D'Aguiar, Shamsie, and Kay all seem to feel involved in what they portray, creating the impression that although the experiences are not their own, the stories are in some senses theirs.

These works contribute to new forms of memory culture by challenging hegemonic constructions of imperial history and inserting into them the voices of the forgotten, the dispossessed, and the defeated. If they can be considered autofictional in any useful way, it is because of how their paratextual apparatus invokes an authorial "I" that not only supplements but is actively conjoined with the subjective experiences of the different human lives they narrate. This dialogue between text and paratext points to a specific way of deploying autofiction, not necessarily as a categorical definition, but as a mode of writing which flares up at specific points in the text to affirm the connection between author and subject. In what follows, I suggest that in different ways Adichie and Cartwright also apply some of the methods afforded by autofiction to re-inscribe themselves into narratives of the Nigerian Civil War (1967-1970) and the massacre of Zulus at Blood River (1838), in stories which are not just theirs, but more than theirs.

\section{Chimamanda Ngozi Adichie's Half of a $\Upsilon_{\text {ELLOW }}$ SUN}

In a comparative study of the diasporic literatures of what he calls the Afro-American and Caribbean traditions, Ndubuisi Martins Aniemeka has argued that thematic preoccupations, especially of a political or historical nature, have received more critical attention than autobiographical writing in each case. Drawing on a model of textual kinesis proposed by Aderemi Raji-Oyelade (2000), according to which character construction and plot trajectory become incorporated into aspects of a physical or metaphorical journey in order to conceptualize and articulate experiences of conflict, he then proposes a model of "characterology" $(2019,11)$, whereby authors are understood by their readers to have imbued fictional characters with aspects of their own experiences and/or aspirations in order to express 
"struggle, identity and cultural survival in purposively selected self-fictional text[s]" (10). Examples Aniemeka finds of this purposive selffictionalization in the literatures of the Afro-American and Caribbean diasporas include Zora Neale Hurston's Dust Tracks on the Road (1942), Richard Wright's Black Boy (1945), George Lamming's In the Castle of my Skin (1953), V.S. Naipaul's House for Mr Biswas (1960), Michael Anthony's The Year in Fernando (1965), and Maya Angelou's I Know Why the Caged Bird Sings (1986). He concludes: "A plot characterology reveals the transmutability of the characters in the texts examined. Apart from such reconstructive ideology couched in the self-writings of these authors, the network of transformation is occasioned by the readercharacters' analytical mapping to awareness" (19-20). These comments suggest that the purpose of restoring a sense of biographical agency to the authors in question is to attempt a degree of social and political transformation through the raising of a new form of critical consciousness that combines individual experience with collective struggle, especially between dominated or marginalized communities and dominant ones. Yet, the awkward term "self-writings" does not quite succeed in elaborating a sense of how these techniques are different from those of straightforwardly autobiographical fiction.

A somewhat different approach to diasporic writing is propounded by Amber Lascelles. In a discussion of Edwidge Danticat's short story "Caroline's Wedding" and Chimamanda Ngozi Adichie's story "Imitation" from the collection The Thing Around Your Neck (2009), she suggests that theories of diasporic writing have focused too greatly on the migrant subject's continued attachment to their country of origin, such that it becomes both mythologized, rendered the object of a restorative nostalgia, and cathected as the symbolic repository of both personal and familial value. Lascelles's point is not that these things do not happen, but that too great a concentration on the home country fails to make possible a dynamic conceptualization of the experiences of the migrant subject in the new or host country. This is especially true among second- or third-generation subjects, whose ties to the home country, though tangible in many ways, are likely to be less strong than those of their parents and grandparents. Moreover, since applying for such legal statuses as the right to work, right of residence, and ultimately rights of citizenship is also more prevalent among later generations, the refusal of the category of diasporic writers, in Lascelles's account, enables the expression of a greater degree of equality among second- and third-generation migrants with regard to the 
population of the host country than was the case for their forebears, who were likely to be extremely marginalized. This realization prompts Lascelles to bring forth the suggestion: "Reading [Danticat and Adichie's] stories comparatively allows me to explore whether new frameworks and terminologies, centrally the emerging term post-diaspora, are useful to capture the complexity of diaspora and its meaning in the twenty-first century" $(2020,227)$. In the context of her wider argument, the adoption of the term "post-diaspora" by Lascelles seems like a logical choice to refer to the literature she discusses (although it should be noted that she also critiques the accompanying implication that the distinction between diasporic and post-diasporic writings is of a binary nature). Combining Aniemeka's attention to diasporic autobiographies and other forms of self-writing with Lascelles's insight into post-diasporic experience makes it possible to suggest here that autofiction can be considered among the new frameworks and terminologies adumbrated by Lascelles.

Elena Murphy (2017) has shown that in many of the stories in The Thing Around Your Neck (2009), Adichie “adeptly queries Western ways of perceiving and defining the African Other from the position of different and diverse characters and, at the same time, the distance from Nigeria allows her to reflect upon her culture of origin" $(2017,101)$. A similar description could be applied to Adichie's novel Americanah (2013) in which the main character Ifemelu migrates between Nigeria and the USA and blogs about her experiences. Miriam Pahl has shown that following publication of the novel, Adichie "transfer[ed] this fictional blog into the real world (wide web)" and continued it under the title "The Small Redemptions of Lagos" in order to demonstrate "a strong political and social commitment" $(2016,77)$. This leads Pahl to conclude that "[a]lthough the experiences depicted in the novel should not be taken as autobiographical information, they do elucidate Adichie's carefully honed public persona" (78).

These insights alone seem like fertile ground for approaching Adichie's work as autofictional, especially in the light of Bran Nicol's suggestion that one of the features of autofiction in North America (where Adichie works) is that it is "best regarded less as a form which interrogates the complex workings of memory and their effect on subjectivity and more as evidence of the preoccupation with the conditions of authorship, especially institutional" $(2018,257)$. The current chapter, however, takes a slightly different approach, not merely classing Adichie as a writer of autofiction but also expanding our theoretical understanding of the concept itself. It is to 
Adichie's novel Half of a Yellow Sun (2006) that we can turn for a fuller articulation of this new combination of post-diasporic writing with the collective potential of autofiction as a means of building forms of solidarity with marginalized peoples and achieving alternative forms of collective memory.

Half of a Yellow Sun is a novelistic history of the Biafran War in Nigeria (1967-1970) focusing on five main characters and alternating between their lives in the early 1960s and at the end of the decade, to situate the war in the context of the historical double coup that was the immediate occasion for it. This coup had occurred partly because the artifact now known as Nigeria itself had only been created by British colonizers during the imperial period, so that when its post-independence administration became corrupt there was first a coup to remove it followed by a countercoup directed against the ethnic Igbo people who were the main protagonists of the first and who were perceived to have become too powerful as a result of it, to the detriment of Nigeria's other ethnic groups, especially the Hausa and Yoruba. Moreover, the federal leader Gowon was thought to have betrayed the Igbo by forming a compromise between them and the central government, and so his counterpart Ujukwu declared Biafran independence.

At the start of the novel the protagonist Odenigbo is an academic in the university town of Nsukka, the town where Adichie was raised and where her father was also a university academic. Although the novel is not written in the first person and so violates Doubrovsky's criteria for autofiction, both setting and profession hint at a close alignment between the family of the author and the historical action depicted in the novel, but places it at a generation's remove from her. Adichie was born seven years after the Biafran War and raised on a university campus, not to mention in a country that had been torn apart by the war. So, although the characters in the novel are an invention, the historical story that her book narrates informs her life to a great degree.

There is a significant metafictional aspect to Half of a Yellow Sun because the main plot is interspersed with extracts from a book-withinthe-book, a manuscript entitled "The World Was Silent When We Died," which readers assume to be by the British scholar, Richard. This character is a conventional figure of European cultural authority who had already attempted two books: "The Basket of Hands," which gets burned by Kainene when she finds out he slept with Olanna; and "In the Time of Roped Pots," which gets left behind buried in his garden in Port Harcourt 
by his houseboy Harrison when he evacuates (Adichie 2006, 182, 170). Both are about the ancient art of rope making, how intricate and refined it is and hence how it demonstrates evidence of a sophisticated civilization and culture existing in Nigeria before the arrival of European colonizers (although Richard is rebuked by a guest at one of Odenigbo's soirées for expressing surprise at this). As readers are led to assume that the extracts from "The World Was Silent When We Died" are also by him, it is a surprise when the last line of the novel reveals that they are in fact by Odenigbo's old houseboy, Ugwu. Although the other houseboy, Harrison, has given up writing by then, Ugwu's new critical literacy may be a sign of hope for the future. This metafictional aspect is significant for two reasons. First, it allows Adichie to participate in the form of metafiction that is particular to postcolonial writers struggling to overcome a common inferiority complex with regard to the apparently rich literary traditions of Europe. Second, it enables Adichie to bear witness to historical events which she did not, in fact, experience, but which nevertheless played a strong part in shaping the society in which she was raised and hence in her own life.

Reading Half of a Yellow Sun as an autofictional contribution to the building of a post-conflict memory culture makes it possible to extrapolate the novel's retrospective reconstruction of conflict as a form of testimony. The novel follows earlier autobiographical accounts of the Biafran War such as Elechi Amadi's Sunset in Biafra (1973), which narrates the author's bitter experiences with the authorities of Biafra during the war. Yet, a key difference is that, as Kalu Wosu points out, Amadi's war narrative "condemns the domineering attitude of the Igbos who, according to the author, dragged other ethnic minorities of the defunct Eastern region into a senseless and brutal war" $(2018,122)$, whereas Adichie wrote "out of solidarity for the oppressed Igbo people" (129) so that in Half of a Yellow Sun "all the characters killed during the war were Igbo, the theatre of war was the Igbo heartland, the refugee crisis affected the Igbo only, the Igbo suffered the Abandoned Property issue, and the pogroms took place only in the Northern parts of Nigeria" (Wosu 2018, 129). Such violence is represented in the novel when Olanna's Aunty Ifeka, Uncle Mbaezi, and cousin Arize are killed in the Northern town of Kano; when Olanna only escapes from Kano on the last train out of the town, on which she meets a woman carrying a calabash containing the severed head of her murdered daughter; when Richard has a similar experience trying to get a flight out of Port Harcourt and witnesses Hausa troops shoot all the Igbo 
people they find, including a young airport official executed for refusing to recite "Allahu Akbar" at the troops' demand because his accent would have given him away as Igbo (Adichie 2006, 152). It is also conveyed through such details as the doctor who attends the refugee center where Kainene works as a volunteer being spat on by a woman he has come to help because he is not Igbo; through the fact that the poet Okeoma and scientist Ekwenugo, who had been regulars at Odenigbo's salons before the war, both die during it; through the fact that Ugwu's sister Anulika is raped by federal soldiers occupying Biafra and his girlfriend Eberechi is killed on the last day of the war. These details bear witness to the historical experience of the Igbo people during the war because as Wosu points out, although the precise characters are literary inventions, Adichie "relied on historical facts to craft her work of fiction" in a way that "blends historical evidence with literary creativity" (Wosu 2018, 123).

On the other hand, Wosu also emphasizes that the nature of a historical experience like a civil war makes drawing a simple dividing line between aggressors and victims somewhat untenable. In the case of Biafra, this is partly because the Igbo were "part of the failed political leadership of the First Republic which led to the crisis" and partly because it is impossible to imagine that there were "no reprisal killings in the East in response to the pogroms in the North" or "even in the North, by Igbos who resisted the pogroms." Yet, Half of a Yellow Sun "is silent on this particular issue" (Wosu 2018, 130). Speculating on potential reasons for this very significant omission leads Wosu to three distinct findings. First, that because Adichie's writing is a medium for both preserving and disseminating the collective cultural memory of the people of Biafra, the overall effect is that the book "makes a strong case for the Igbo nation" (130). Although interpreting Adichie as an advocate of Igbo nationhood is a somewhat extreme and unconventional approach to her work, this bears on the second finding, namely that, because the post-independence nation of Nigeria was defined in a territorial sense by the parameters of the British colony there, the nation itself is in part constituted by its colonial history. This is both why Britain supported the republic against the secessionist Biafran movement during the war, and why its whole history has been constructed according to the logic of what Wosu calls "western logocentrism" (2018, 131). By centering her narrative on the Igbo rather than other Nigerian communities such as the Hausa, Ikwerre, or Yoruba, Adichie rewrites that logocentric history, revealing that the "binary opposition black/white is a 
western construct which, at the discursive level, seeks to give the European an imaginary ascendancy over the African" (131).

In making this point, Wosu performs a slippage from one form of binary differentiation (between federal Nigerian aggressors and traumatized Igbo secessionists) to another (between European colonizers and African colonized). There is a certain logic that makes this slippage possible, as the territory of independent Nigeria was geographically defined by that of the British colony which preceded it, so that to critique the yoking together of many different peoples and ethnicities on the basis of the shared experience of having been colonized by Britain, is to simultaneously critique both the post-independence state and its prior colonial determinants. Yet, if a refusal of the categorical distinction between black and white or between Africa and Europe is one of the philosophical insights to emerge from Wosu's reading of Half of a Yellow Sun, this refusal would presumably apply equally to both the Igbo people and the other ethnic communities in Nigeria. Given that the novel appears to recruit historical understanding for the Igbo in contrast to those other groups, it is difficult to see how this commonality can be envisaged in the text in practice.

A solution to this challenge is suggested by Wosu's third key finding, which is about how Adichie handles the relationship between fact and fiction: "'Fact' still remains for us literally 'a thing done.' And fiction has never lost its meaning of 'a thing made"' $(2018,124)$. This distinction usefully informs an extrapolation of the potential for reading Half of a Yellow Sun as a form of autofiction, revealing that what we encounter in the text is not so much Adichie telling her own story as creating a collective story of the Igbo people (which includes her) and of Nigeria as a whole (which includes the Igbo). This creation is made in the service of forging a new form of reconciliation in the present, based on shared memory and an alternative collective relationship to the Civil War and to the past. Such striving would have been especially necessary a generation after the war because as Wosu shows, the "reconciliation, reconstruction, and rehabilitation which [Nigerian leader] General Gowon promised [after the war] ended up as a hoax" $(2018,131)$. That is, Adichie uses the novel to attempt a fictional version of the post-war reconciliation that the Nigerian state failed to deliver historically. Elena Murphy notes that Adichie "describes herself as belonging to the Engli-Igbo generation of Nigeria and this shows in her works, where what could be defined as a 'transcultural form of English' is employed" $(2017,99)$. English as a transcultural 
tool enables the novel to speak to and for all the different peoples within Nigeria and transcend their differences. This commitment to overcoming enmity, rather than the strictest representation of verifiable, factual truth, enables Adichie to portray the war but also to begin consigning it to the past. Or as Wosu puts it: "Reality is thus relative, and the author tries to reconstruct it in her quest for a new wholesomeness" $(2018,130)$. The story of the Biafran War is not Adichie's but that of the people to whom she relates, namely, the Igbo. Half of a Yellow Sun can thus be seen as autofiction on a collective scale. It not only narrates how Adichie and the Igbo fit into the Nigerian whole but actively works toward such integration.

\section{Shared Heritage in Up Against the Night}

Writing from a different context to Adichie, the South African-born writer Justin Cartwright (1943-2018) was interested in exploring different kinds of truth and investigating how subjective and objective truths complicate each other without easy resolution. For example, his 1993 novel Masai Dreaming is about a filmmaker, Kurtiz, traveling to Kenya in the 1990s to make a documentary about a female French Jewish anthropologist who had lived and worked there in the 1930s and 1940s. Her love affair with a Masai farmer, who was subsequently executed, so outraged her English lover that he demanded that she be tested for syphilis and while traveling to Paris to have this test she was arrested by the Nazis and sent to her death. Yet, in the film made about her life in the 1990s, this detail is altered so that she escapes back to Kenya via Cape Town because the filmmaker feels such an ending is a better way of affirming the supposedly universal spirit of the Masai people, whose way of life was in fact on the brink of extinction. Through these plot details, Cartwright shows Kurtiz exploring a series of dilemmas about what a writer owes to art and to truth, and how these things relate to each other, especially with regard to the uncomfortable truth that a number of French people had been complicit in the Nazi roundup of French Jews at Drancy.

Cartwright's narrative exploration of the relationship between truth, art, and meaning continues in his next novel, In Every Face I Meet (1995), portraying a South African banker in London who has a powerful childhood memory of watching a tribal Swazi king dance at an annual ceremony of cultural renewal and who pins his hopes for redeeming the failed aspirations of Thatcherism on another tribal Prince, Nelson Mandela. Before he can fly out to watch Mandela's release from political prison he is 
mugged at gunpoint by a black youth and ends up on trial for murdering the mugger. Although he is acquitted, he feels somewhat morally ambivalent, even guilty, suggesting that his privilege as a white banker compared to the young black attacker might explain the original mugging even if it does not condone it. Interracial violence and questions of both forgiveness and reconciliation-which in South Africa in the year of Mandela's release had very broad and powerful implications for the whole society-are thus revealed to be highly complex and no easy answers are envisaged by the novel.

The role of art in mediating potential responses to the questions "What is truth?" and "What is good?" is even more explicitly the focus of Cartwright's later novel The Promise of Happiness (2004) about a London accountant who is pushed out of his own firm during a hostile takeover. The accountant and his wife retire to Cornwall to plan the marriage of their son to a glamorous but unintellectual South American model whom they doubt will make him happy. In turn the son has spent two years visiting his older sister in prison in America, where she was convicted for her role in fencing a Tiffany stained glass window believed to have been stolen from a cemetery years earlier, on behalf of her boyfriend, the British owner of a New York art gallery. She seems to have taken the blame partly to protect him from a longer sentence and partly out of guilt, as she had been too distracted by a love affair with an American writer to notice that the gallery was in financial trouble. Moreover, when she is released, a New York Times journalist discovers that the window was never actually stolen. Rather, an ambitious FBI agent eager to improve his clean-up rate for art crimes had orchestrated the affair. There are thus as many "truth" of the event as there are stories about it. As in Umberto Eco's Prague Cemetery, the scene in which the valuable window had originally been stolen is different each time it is re-told, and the role played by art and artifice in each re-telling is explicitly foregrounded by the novel.

An idiosyncratic feature of The Promise of Happiness is that although for the most part it is narrated in the third person, it frequently shifts into the first to get inside the thoughts of whichever character is thinking at the time. At one specific point during a meditation on the human propensity to imagine angels as a symbol for uncorrupted happiness, the phrase "The author..." is also used in this way:

Another thing about angels: they are not direct participants in life's struggle: they are above it. And that's why we like them. They are disinterested 
observers, impartial do-gooders. They only acquired wings in later centuries. The author thinks that they were a necessary invention, an antidote to the harshness of religion and a comfort in death. $(2004,138)$

The technique of dispersed focalization shifting between one character and another appears to have given rise to a situation in which ideas cannot be conceptualized if they are not associated with the particular character experiencing them. So ideas not explicitly owned by a specific character cannot be expressed in any other way than by invoking the author as a briefly active character, and the presence of Cartwright obtrudes.

This sallying forth of the authorial presence is even more detectable in Cartwright's final novel, Up Against the Night (2015), in which Cartwright returns to a number of themes that had characterized the works discussed above: the relationship between Britain and a number of African countries; experiences of migration between countries and continents on a global scale; the question of value, what confers it and what confers meaning on it; plus the matter of how art relays these questions to us while also being implicated in the very problematics it raises. Cartwright had already used the metafictional device of having a main character who is a filmmaker in Masai Dreaming (1993), and had associated his disillusioned banker's search for transcendental meaning with his own reading of current affairs in In Every Face I Meet (1995), so that an interest in the role of the artist in addressing questions of meaning, value, and ethics was already present in these earlier novels but without an explicit use of autofiction. Autofiction then starts to enter his work in The Promise of Happiness (2004), though only in a brief and occasional way at this point. In $U p$ Against the Night (2015), Cartwright portrays a protagonist who shares a number of his own biographical details, and thereby more explicitly uses the techniques of autofiction to explore the same themes that had interested him all along. In other words, he appears to have been gradually and increasingly attracted to autofictional modes of writing throughout his career and this process reaches its zenith in his final novel, which revisits thematic material that he had already explored in earlier work, with a greater degree of self-awareness and critical self-consciousness than before.

Read alongside the earlier texts, Up Against the Night thus reveals a higher degree of autofictional writing in its portrayal of the coming to terms with the uneasy colonial past in South Africa. The protagonist, Frank McAllister, is in his 60s and, having retired from a prosperous career in England, increasingly finds himself feeling out of place and looking to 
South Africa, where he was born and where his mother died during his childhood, for a sense of belonging. His sense of not belonging is conveyed through minor details like the fact that he is in the process of separating from his spoiled, fashion-conscious wife Georgina. Frank's feeling of dislocation is also conveyed through the fact that his old friend and colleague Alec has made a fool of himself by allowing a young Latvian pole dancer whom he had promised to put through university to abscond with half a million pounds, has suffered a minor stroke since retiring, and later dies of a second stroke. The sense of alienation is further compounded by the fact that Frank's daughter Lucinda is in a drug rehabilitation clinic in California, and his distant cousin Jaco Retief has been imprisoned by the church of scientology in the USA and needs US\$50,000 to bail him out.

This last character is especially relevant in considering the novel as an autofictional contribution to emerging memory cultures in South Africa, as not only are Frank and Jaco both descended from Piet Retief, the nineteenth-century leader of the Boer settlers in the Zulu territories of what is now KwaZulu-Natal in South Africa, but the jacket blurb of Up Against the Night tells us that this is also true of the author Justin Cartwright himself. It was noted at the start of this chapter that paratexts have a crucial role in signaling texts as autofictional, since autofictional texts raise truth claims that can be judged only by looking outside the text proper. The paratexts are the pivots between the words of the main body of text and the world to which it relates. In the case of Up Against the Night, the paratextual biography given in the blurb, and other paratextual apparatuses, such as Cartwright's obituary in the Guardian (Kean 2018), cultivates a strong connection between the protagonist and the author.

Like Cartwright, the aging Frank is portrayed as becoming both conscious of his own mortality and more reflective of his South African origins, causing him to research the killing of Retief and his followers by the Zulu leader Dingane in 1838. The Great Trek across the Eastern Cape that Retief had led is often presented in Boer and Afrikaner folklore as a narrative tantamount to a foundational myth or moment of origin for the culture as a whole. But Frank's research causes him to feel that the truth is both more complicated and more morally ambivalent than this. Although the death of Retief took place in a massacre of Afrikaners by Zulus, which is narrated in the historical passages in Up Against the Night, Frank is unable to condemn the Zulu leader Dingane's acts, as it was clear that Retief did not intend to abide by the existing peace treaty, and in fact meant to dispossess the Zulus of their land. On the other hand, the fact 
that Piet was Frank's ancestor makes him feel a connection with him despite himself. He feels further ambivalence because in retaliation for the killings, the remaining Boers wiped out virtually all the Zulus in the Battle of Blood River, and this is again a history from which Frank cannot distance himself however much he may feel ashamed of it, because in an affective sense it is his own history, so that to deny it would be to deny a part of his own existence. Given that Cartwright has endowed Frank with his own Retief ancestry, although the plot of the novel is invented, Frank's dilemmas can in a meaningful way be described as Cartwright's own.

As often in Cartwright's oeuvre, artistic work is mobilized as a vehicle for exploring these dilemmas. One of the recurring motifs of the novel is a memory Frank has of watching a moving production of Macbeth performed in Johannesburg by a Zulu cast. This precise choice of play (about political violence, murder, and revenge) contributes thematic material to the novel's wider exploration of the rights and wrongs of a violent power grab in the historical past and of its long-term historical reverberations in the present. Moreover, the selection of a work by perhaps the most archetypally English dramatist, Shakespeare, being performed by a Zulu cast emphasizes Frank's dual heritage, in which the European and African elements complicate each other.

In his extended reflective engagement with a dubious political past that can be neither fully embraced nor entirely disclaimed, Frank is thus an avatar for Cartwright. Frank's personal implicature in a heritage he deems morally repellent causes him constantly to seek endless alternative ways of belonging. The complexities involved in that attempt are contrasted with the character Jaco, an unreflective privileged white South African who continually laments the state of the nation since the ending of apartheid, criminalizes the black population, and, in an apparently self-fulfilling prophecy, shoots a group of black armed robbers in order to rescue both Frank and Nellie, along with Frank's daughter Lucinda and the baby she has brought with her from America, Isaac.

Through this baby Cartwright brings the disparate relatives together, and in this sense follows a very common trope in postcolonial writing whereby the late arrival of a baby symbolizes uneasy reconciliation with the past and a feeling of hope for the future. In the quite convoluted plot structure-Isaac is the biracial son of Lucinda's ex-boyfriend's exgirlfriend, causing Frank to wonder if Lucinda is even legally permitted to travel with him as he is not her baby-this trope has an additional effect. The classic fictional plot device of the swapped baby hints simultaneously 
at a relationship of connection and separation. And this, of course, is what both Frank and Cartwright feel about their shared colonial ancestor, Piet Retief, so that like Adichie's Half of a Yellow Sun, Up Against the Night produces a feeling of autofiction at one remove. Cartwright's book ends with Frank going to Sotheby's to collect a Howard Hodgkin painting Alec gifted him as a wedding present. Its abstract landscape makes him think first of the descriptions of blood draining into the ground after the massacre of Piet in 1838, and then of the blood soaking his own house in Cape Town after the recent shooting. He realizes that his life, and in some ways the history of his family, has come full circle. There is thus a convergence between the content of the novel, which is entirely fictional, and the family history of the author, which is not.

\section{Autofiction and Memory Cultures}

In a discussion of Achmat Dangor's novel Bitter Fruit (2001), about a woman who was raped in apartheid-era South Africa and comes face to face with her rapist during the sessions of the Truth and Reconciliation Commission (TRC), through which the post-apartheid nation attempted to heal the wounds of the past, Ronit Frenkel says:

The inconclusive nature of such archaeological endeavours therefore becomes paramount to understanding the TRC and the construction of histories in South Africa, where the consequences of either recalling or suppressing the past are severe, because ultimately post-colonial pathos shapes all response and history cannot be redeemed. $(2008,84-85)$

To a large degree, this comment could be applied to any novel that deals with the politics of memory and reconciliation in post-apartheid South Africa. Up Against the Night is distinctive for the way it evokes a sense of Cartwright being personally implicated in the process of coming to terms with the past. Such a feeling is then supported by the paratexts and enforced by the parallel plotlines about Piet Retief in the past and Frank McAllister in the present. To the extent that Frank is constructed as a discernible avatar of Cartwright, the novel can therefore be considered autofictional in its dealing with the politics of memory. It represents a conjunction of personal experience with collective history in its evocation of the difficulties inherent in building new forms of memory culture in a society emerging from historical conflict. 
Interpreting Adichie's work as an instance of autofiction elucidates a different form of post-conflict narrative and reconciliation. It was suggested above that there are many grounds on which Adichie's work could be considered autofictional: her application of autobiographical elements to fiction, her careful control of her public persona as author, and the sense her work evinces that the stories she tells are almost, if not quite, her own. This last point is the main argument that has been developed here. The chapter explored how the autofictional dimension of Adichie's work enables an active engagement by the author with questions of public memory with regard to a conflicted past and its reverberations in the present.

Both Cartwright's and Adichie's works create the feeling that the stories they tell in some senses both are and are not their own. They are stories of historical events that unfolded before either of them was born, but which nevertheless have cast shadows over their lives and played a powerful part in determining their subjectivities and those of the people in the societies they come from, in the present. Autofiction in this context can be understood to open a narrative space in which those historical conflicts and their latter-day ramifications can be explored. Thus, the combination of autofiction and post-conflict narratives that has been discussed throughout this chapter provides a powerful means of contributing to new forms of public memory and to affective forms of reconciliation. In turn, this new combination expands and enriches our understanding of autofiction itself.

\section{Note}

1. “Ce qui m'intéresse particulièrement, sans doute parce que j'en observe les effets en moi-même, c'est la question du clivage. Le moi n'est pas fixe, nous n'avons pas une identité simple et monolithique, nous sommes faits de tensions entre nos différents avatars intimes. 'Je sommes,' devrions-nous dire."

\section{Works Cited}

Adichie, Chimamanda Ngozi. 2006. Half of a Yellow Sun. London: 4th Estate.

- 2009. The Thing Around Your Neck. London: 4th Estate.

- 2013. Americanah. London: 4th Estate. 
Aniemeka, Ndubuisi Martins. 2019. Ambivalent Identity and Self Repatriation in the Plot Characterisation of Selected Black Auto/Biographical Novels. International Journal of English and Literature 10 (2): 9-20.

Cartwright, Justin. 1993. Masai Dreaming. London: Sceptre.

- 1995. In Every Face I Meet. London: Sceptre.

- 2004. The Promise of Happiness. London: Bloomsbury.

- 2015. Up Against the Night. London: Bloomsbury.

Colonna, Vincent. 2004. Autofiction \& autres mythomanies littéraires. Auch: Tristram.

D'Aguiar, Fred. 1997. Feeding the Ghosts. London: Chatto \& Windus.

Dix, Hywel. 2020. Autofiction, Colonial Massacres and the Politics of Memory. University of Bucharest Review 22 (1): 10-22.

Doubrovsky, Serge. 1977. Fils. Paris: Galilée.

Frenkel, Ronit. 2008. The Politics of Loss: Post-Colonial Pathos and Current Booker Prize-Nominated Texts from India and South Africa. Scrutiny 2: Issues in English Studies in Southern Africa 13 (2): 77-88.

Hanczakowski, Allira. 2020. Uncovering the Unwritten: A Paratextual Analysis of Autofiction. Life Writing, published online July 29, 2020. https://doi.org/1 $0.1080 / 14484528.2020 .1801132$.

Kay, Jackie. 2011. Fiere. London: Picador.

Kean, Danuta. 2018. Justin Cartwright Obituary. The Guardian, December 20, 2018. https://www.theguardian.com/books/2018/dec/20/justincartwright-obituary. Accessed Apr 5, 2021.

Lascelles, Amber. 2020. Locating Black Feminist Resistance through Diaspora and Post-Diaspora in Edwidge Danticat's and Chimamanda Ngozi Adichie's Short Stories. African and Black Diaspora: An International Journal 13 (2): 227-240.

Laurens, Camille. 2016. Entretien avec Camille Laurens à propos de son ouvrage Celle que vous croyez. Babelio, April 7, 2016. https://www.babelio.com/ auteur/Camille-Laurens/13674. Accessed Apr 5, 2021.

Missinne, Lut. 2019. Autobiographical Novel. In Autobiography/Autofiction: An International and Interdisciplinary Handbook, ed. Martina Wagner-Egelhaaf, 464-472. Berlin: De Gruyter.

Murphy, Elena Rodríguez. 2017. New Transatlantic African Writing: Translation, Transculturation and Diasporic Images in Chimamanda Ngozi Adichie's The Thing Around Your Neck and Americanah. Prague Journal of English Studies 6 (1): 93-104.

Nicol, Bran. 2018. Eye to I: American Autofiction and Its Contexts from Jerzy Kosinski to Dave Eggers. In Autofiction in English, ed. Hywel Dix, 255-274. Cham: Palgrave Macmillan. 
Pahl, Miriam. 2016. Afropolitanism as Critical Consciousness: Chimamanda Ngozi Adichie's and Teju Cole's Internet Presence. Journal of African Cultural Studies 28 (1): 73-87.

Raji-Oyelade, Aderemi. 2000. Character Theory in the Black Novel. In The Black Novel, ed. Asha Viswas, 29-40. New Delhi: Bahri Publications.

Saunders, Max. 2010. Self Impression: Life-Writing, Autobiografiction, and the Forms of Modern Literature. Oxford: Oxford University Press.

Shamsie, Kamila. 2014. A God in Every Stone. London: Bloomsbury.

Worthington, Marjorie. 2018. The Story of "Me": Contemporary American Autofiction. Lincoln, NE: University of Nebraska Press.

Wosu, Kalu. 2018. Writing and Discourse: Chimamanda Ngozi Adichie's Half of a Yellow Sun as a Civil War Narrative. Africology: The Journal of Pan African Studies 12 (2): 121-133.

Open Access This chapter is licensed under the terms of the Creative Commons Attribution 4.0 International License (http://creativecommons.org/licenses/ by $/ 4.0 /$ ), which permits use, sharing, adaptation, distribution and reproduction in any medium or format, as long as you give appropriate credit to the original author(s) and the source, provide a link to the Creative Commons licence and indicate if changes were made.

The images or other third party material in this chapter are included in the chapter's Creative Commons licence, unless indicated otherwise in a credit line to the material. If material is not included in the chapter's Creative Commons licence and your intended use is not permitted by statutory regulation or exceeds the permitted use, you will need to obtain permission directly from the copyright holder.

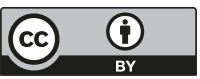

